\title{
Identification and Antibiogram of Mastitis Pathogens Isolated from Bovine and Caprine Clinical Mastitis in Wayanad District- Kerala
}

\section{Ranjini Manuel ${ }^{1 *}$ and Deepa $\mathbf{P M}^{2}$}

1,2 Department of Veterinary Epidemiology and Preventive Medicine, Kerala Veterinary and Animal Science University, Pookode, Kerala, India

*Corresponding Author: Ranjini Manuel, Department of Veterinary

Epidemiology and Preventive Medicine, Kerala Veterinary and Animal Science

University, Pookode, Kerala, India.

DOI: $10.31080 /$ ASVS.2022.04.0342
Received: February 21, 2022

Published: February 28, 2022

(C) All rights are reserved by Ranjini

Manuel and Deepa PM.

\begin{abstract}
The present study included 30 milk samples from animals affected with clinical mastitis for antibiotic sensitivity tests from TVCC, Pookode, and Ambulatory clinic in Wayanad. 18 were bovine milk samples and 12 were goat milk samples. Most of the cases were presented with swelling in the udder, yellowish milk, flakes of pus, serosanguinous discharge, fibrosis of the udder, low milk yield, and edema. Based on the culture and biochemical characteristics, the organism was identified. Out of 30 samples, 13 (43.33percent) was positive for staphylococcus aureus, 7(23.33\%) samples for streptococcus agalactiae, 3(10\%) samples for E coli, 2 (6.66\%) samples for Enterobacter, 1(3.33\%) sample for klebsiella, rest 4(13.33\%) samples had no growth. Antibiotic sensitivity test showed 66.66 percent samples were sensitive to ceftriaxone/tazobactam, 63.33 percent samples sensitive to cefoperazone, 56.66 percent samples sensitive to enrofloxacin, 53.33 percent samples sensitive to Amoxicillin-clavulanate, 50 percent samples sensitive to tetracycline, 40 percent samples sensitive to gentamicin, 26.66 percent samples sensitive to ceftizoxime, 20 percent samples sensitive to co-trimazole and Amoxicillin. The results of the present study demonstrated the growing resistance of frequently used antimicrobials in the case of mastitis.
\end{abstract}

Keywords: Clinical Mastitis; Identification; Antibiotic Sensitivity; Antibiogram; Bovine Mastitis; Caprine Mastitis

\section{Introduction}

Mastitis is the inflammation of the parenchyma of the mammary gland, characterized by physical, chemical, and bacteriological changes in milk and pathological changes in glandular tissues [1]. Mastitis is one of the complex disease conditions among ruminants. Three major types of mastitis are clinical mastitis, subclinical mastitis, and chronic mastitis. In clinical mastitis symptoms are obvious. They include changes in the consistency and colour of the milk. Glandular changes of the udder result in swelling, heat, pain, and induration of the udder. Staphylococcus aureus is one of the most important causes of clinical mastitis [2]. It is estimated that an economic loss of over Rs 6000 crore occurs, out of which Rs 1700 crore are due to clinical mastitis and Rs 4300 crore is due to subclinical mastitis [3]. An important reason for the failure of antimicrobial therapy is the indiscriminate usage of easily available antibiotics without subjecting them to proper antibiotic sensitivity tests.

\section{Materials and Methods}

A total of 30 milk samples of animals positive for clinical mastitis were collected from TVCC Pookode and Ambulatory clinic in the Wayanad district. Out of which 18 samples were bovine milk and 12 samples were caprine milk. All the milk samples were streaked on Brain heart infusion agar, followed by enrichment in nutrient broth, and then streaked on Muller Hinton agar with antibiotic discs. Antibiotic discs used included Gentamicin (10mcg), Ceftriaxone/Tazobactam $(30 \mathrm{mcg})$, Tetracycline $(10 \mathrm{mcg})$, Cefoperazone (75mcg), Amoxyclav (30mcg), Co-trimoxazole (25mcg), Amoxicil- 
lin (30mcg), Ceftizoxime (30mcg), Enrofloxacin (10mcg). Minimal inhibition values were determined by the disc diffusion method. Further, each bacterial isolate's staining and cellular morphological features were ascertained by examination of gram-stained smears. Isolated bacteria were confirmed on the basis of their cultural and other biochemical characteristics like IMViC, catalase and oxidase tests.

\section{Results and Discussion}

Out of 30 samples of clinical mastitis, 18 were bovine milk samples, 12 were caprine milk samples. 10 samples obtained had already been subjected to antibiotic treatment. Symptoms observed were low milk yield, swelling of the udder, yellowish milk, flakes of pus, serosanguinous discharge, fibrosis, and edema of the udder. Growth on media was observed for 26 samples and there was no growth for 4 samples. Of the cultural isolates obtained 16 (61.5\%) were Gram-positive organisms and the remaining 10 (38.4\%) were Gram-negative organisms. The predominant organism identified was Staphylococcus aureus (43.33\%), followed by Streptococcus agalactiae (23.33\%), Escherichia coli (10\%), Enterobacter sp. (6.66\%), and Klebsiella sp. (3.33\%). Antibiogram study revealed that there is high sensitivity for Ceftriaxone/Tazobactam (66.66\%) and Cefoperazone (63.33\%) followed by Enrofloxacin (56.66\%), Amoxclav (53.33\%), Tetracycline (50\%), Gentamicin (40\%), Ceftizoxime (26.66\%), Amoxicillin and Co-trimoxazole (20\%).

Clinical mastitis is one of the most challenging disease conditions affecting both bovines and caprines in the dairy industry. The economic loss contributed by this condition is significant [3]. The high prevalence of Staphylococcus aureus in this study is in accordance with the study conducted by other researchers in India [4-6]. There is a gradual change in the trend of antibiotic sensitivity towards the organisms causing mastitis. Earlier antibiotics like gentamicin, enrofloxacin, and tetracycline were found to be more sensitive [7-9,10]. The present study indicated that there is a drop in the sensitivity towards gentamicin, enrofloxacin, and tetracycline. This change in the trend can be attributed to the growing resistance of the microbes. Indiscriminate usage of antibiotics by the dairy farmers without proper guidance and treatment of mastitis without prior antibiogram tests can be the reasons behind this emergence and change in the resistance pattern.

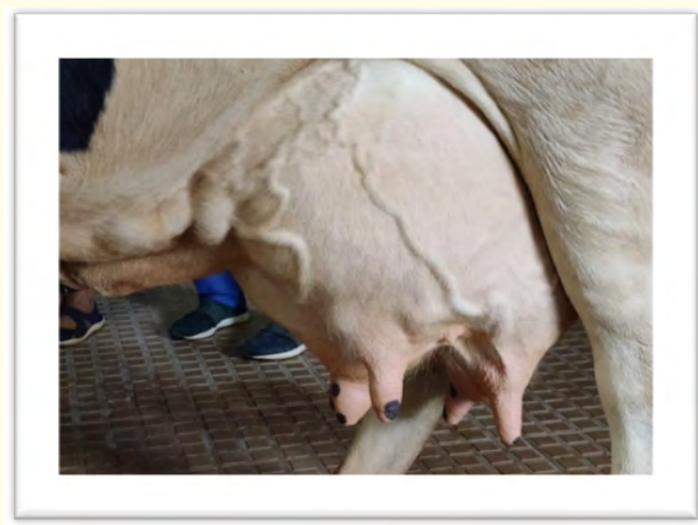

Figure 1: Mastitis in Cow.

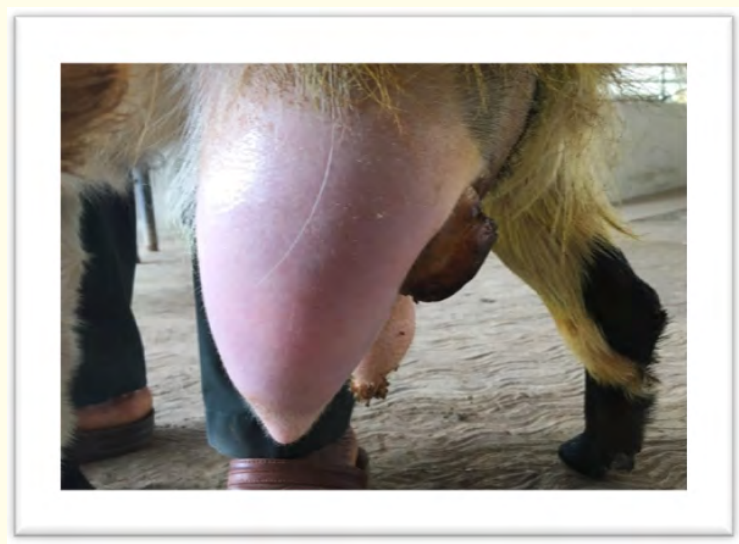

Figure 2: Mastitis in Goat.

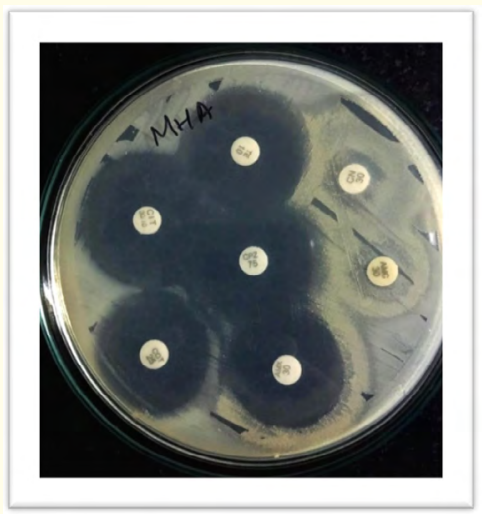

Figure 3: Antibiogram. 


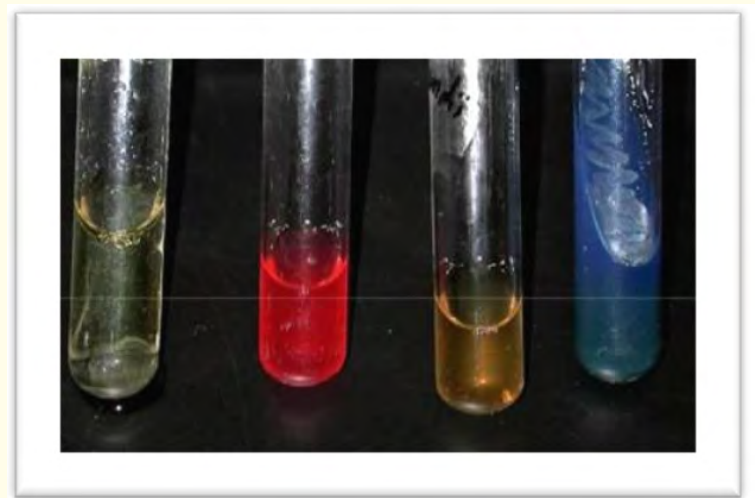

Figure 4: IMViC test +++ (Staphylococcus aureus).

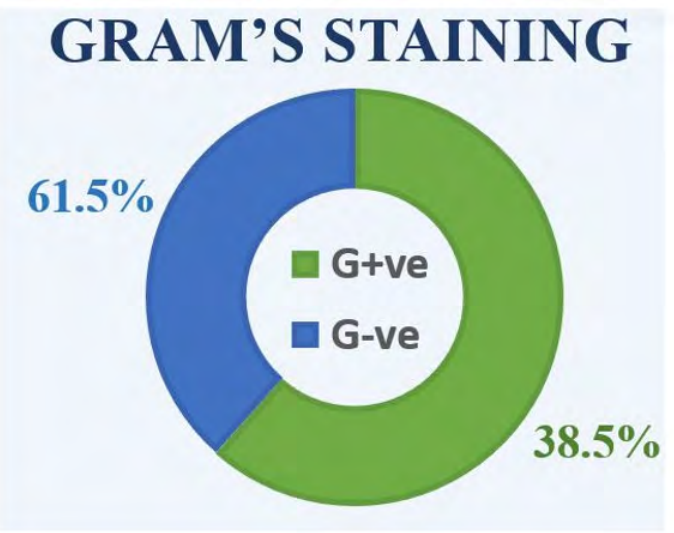

Figure 6: Proportion of gram-stained organism.

\section{ORGANISMS OBTAINED}

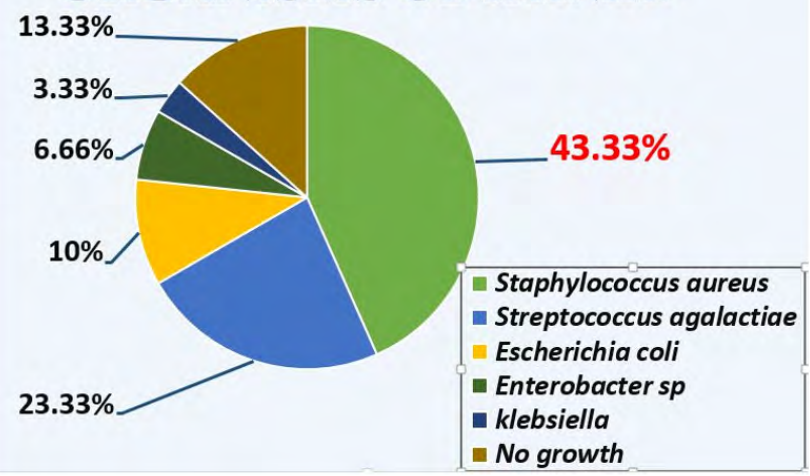

\section{ANITIBIOTIC SENSITIVITY}

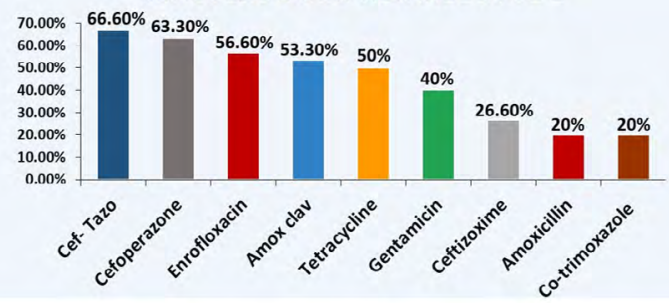

Figure 7: Antibiotic sensitivity.

Figure 5: Organisms obtained.

\begin{tabular}{|l|c|c|c|c|c|c|}
\hline $\begin{array}{l}\text { Sl. } \\
\text { No }\end{array}$ & Species & Symptoms & $\begin{array}{c}\text { Antibiotic } \\
\text { Usage }\end{array}$ & Gram +/- & $\begin{array}{c}\text { Catalase/ } \\
\text { Oxidase }\end{array}$ & Sensitivity \\
\hline 1 & cattle & $\begin{array}{c}\text { Swelling of the udder, } \\
\text { thick pus }\end{array}$ & No & Gram +(strep.agal) & $\begin{array}{c}\text { C -ve } \\
\text { O -ve }\end{array}$ & $\begin{array}{c}\text { Enrofloxacin, gentamicin, cef-tazo, } \\
\text { cefoperazone }\end{array}$ \\
\hline 2 & cattle & $\begin{array}{c}\text { Fever, watery milk, } \\
\text { edema of udder }\end{array}$ & No & $\begin{array}{c}\text { G+ } \\
\text { (staph.aureus }\end{array}$ & $\begin{array}{c}\text { C +ve } \\
\text { O -ve }\end{array}$ & Enro, genta, cef-tazo, cefoperazone \\
\hline 3 & cattle & $\begin{array}{c}\text { Yellowish thick pus, } \\
\text { udder fibrosed }\end{array}$ & No & $\begin{array}{c}\text { G-ve } \\
\text { E. coli }\end{array}$ & $\begin{array}{c}\text { C +ve } \\
\text { O-ve }\end{array}$ & $\begin{array}{c}\text { Amoxicillin, Amox clav, tetracycline, } \\
\text { Enro, cef- tazo, ceftizoxime }\end{array}$ \\
\hline 4 & cattle & $\begin{array}{c}\text { Thick milk, drop in } \\
\text { milk production }\end{array}$ & No & $\begin{array}{c}\text { G-ve } \\
\text { E. coli }\end{array}$ & $\begin{array}{c}\text { C +ve } \\
\text { O -ve }\end{array}$ & $\begin{array}{c}\text { Amox clav, Enro, Tetracycline,cef-tazo, } \\
\text { cefoperazone }\end{array}$ \\
\hline 5 & Cattle & $\begin{array}{c}\text { Swelling of the udder, } \\
\text { serous discharge }\end{array}$ & $\begin{array}{c}\text { Yes } \\
\text { (intacef) }\end{array}$ & $\begin{array}{c}\text { G-ve } \\
\text { enterobacter }\end{array}$ & $\begin{array}{c}\text { C +ve } \\
\text { O-ve }\end{array}$ & $\begin{array}{c}\text { Tetracycline, gentamicin, amox clav, } \\
\text { cef tazo, cefoperazone }\end{array}$ \\
\hline 6 & cattle & $\begin{array}{c}\text { watery milk, hot to } \\
\text { touch }\end{array}$ & yes & $\begin{array}{c}\text { G-ve } \\
\text { E. coli }\end{array}$ & O -ve & $\begin{array}{c}\text { Gentamicin, ceftizoxime, cefoperazone, } \\
\text { amox clav }\end{array}$ \\
\hline
\end{tabular}




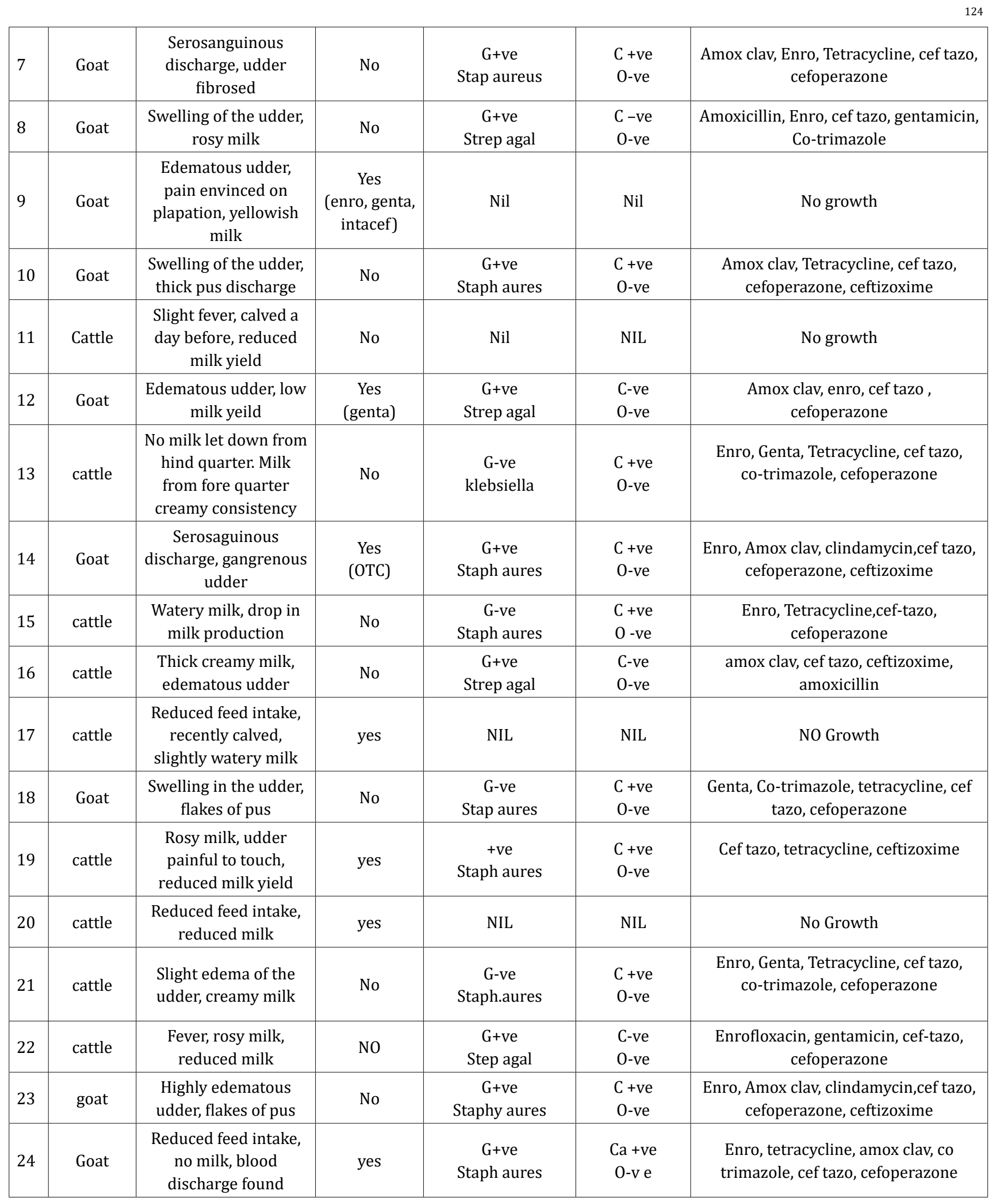




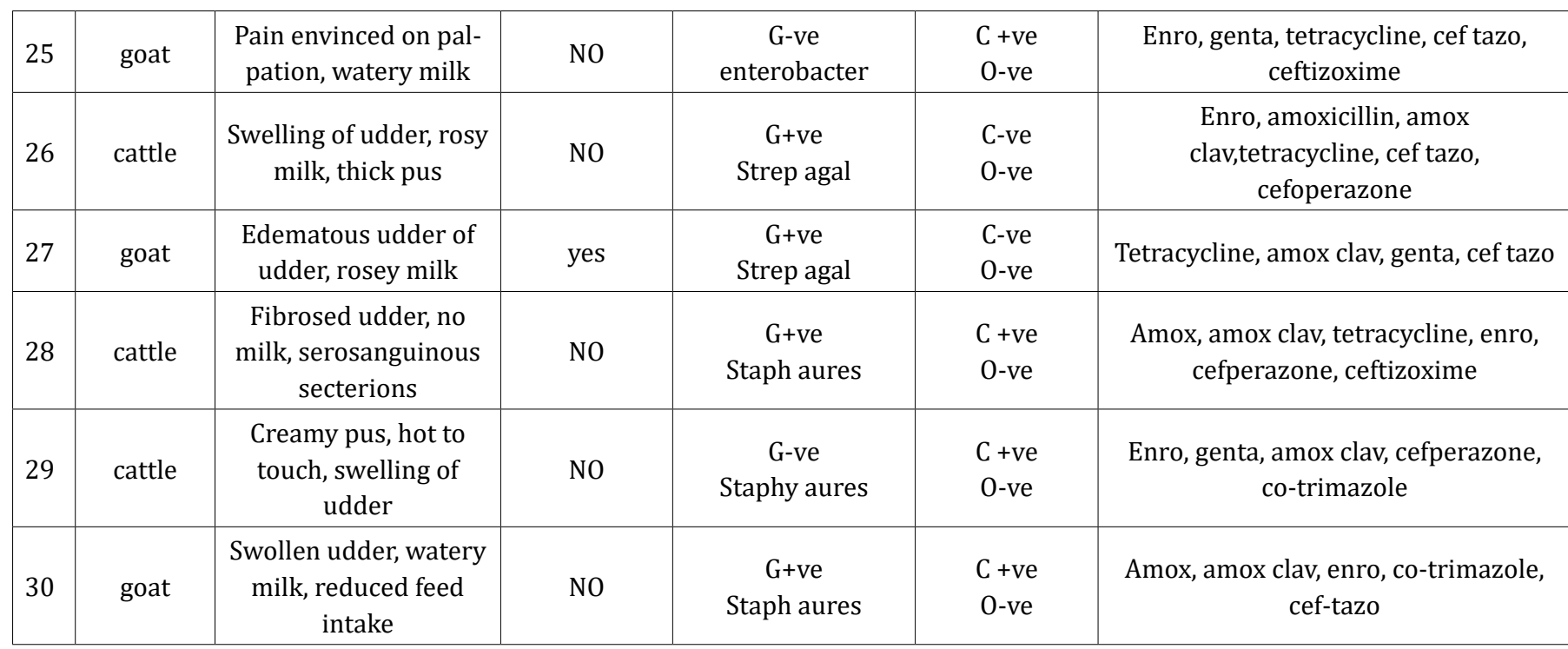

Table a

\section{Conclusion}

Bovine mastitis is a global problem as it adversely affects animal health, the quality of milk, and the economics of milk production. Every country including developed ones suffers huge financial losses from this condition. The emergence of resistant microbes has a huge impact, not only on animal health but also on human health. Indiscriminate use of antibiotics on dairy animals has also contributed to the growing resistance of these antibiotics in humans as well. Diagnosis should be meticulous and strict antibiotic sensitivity tests should be carried out before prescribing any therapeutic instructions. This scenario can be altered only by scrupulous usage of antimicrobials in the future.

\section{Acknowledgements}

Nill.

\section{Conflict of Interest}

I declare that there were no conflicts of interest encountered.

\section{Bibliography}

1. Radostits OM., et al. "Bovine mastitis, In: A Textbook of Cattle, Sheep, Pigs, Goat and Horse". Veterinary Medicine. $9^{\text {th }}$ edition. ELBS and Bailliere Tindau (2000): 563-618.

2. Barkema HW., et al. "Incidence of clinical mastitis in dairy herds grouped in three categories by bulk milk somatic cell count". Journal of Dairy Science 81 (1998): 411-419.
3. Financial daily. "Mastitis: expert calls for early detection". The Hindu group of publication (2002).

4. Jeykumar M., et al. "Antibiogram of mastitis pathogens in the milk of crossbred cows in Namakkal district, Tamil Nadu". Veterinary World 6.6 (2013): 354-356.

5. Awandkar SP., et al. "Prevalence and current antibiogram trend of mastitic agents in Udgir and its visinity, Maharashtra State, India". International Journal of Dairy Science 4.3 (2009): 117-122.

6. Bhatt VD., et al. "Identification and antibiogram of microbes associated with bovine mastitis". Animal Biotechnology 22.3 (2011): 163-169.

7. Sumathi BR., et al. "Prevalence and antibiogram profile of bacterial isolates from clinical bovine mastitis". Veterinary World 1.8 (2008): 237-238.

8. Ranjan R., et al. "Current trend of drug sensitivity in bovine mastitis". Veterinary World 3.1 (2010): 17.

9. Kumar R., et al. "Prevalence, current antibiogram and risk factors associated with mastitis in dairy goats in Punjab". International Journal of Science, Environment and Technology 5.6 (2016): 4580-4593.

10. Sharma N., et al. "Studies on the incidence of sub clinical mastitis in buffaloes of Rajnandgaon district of Chhattisgarh state". Veterinary Practitioner 5 (2004): 123-124. 


\section{Assets from publication with us}

- Prompt Acknowledgement after receiving the article

- Thorough Double blinded peer review

- Rapid Publication

- Issue of Publication Certificate

- High visibility of your Published work

Website: www.actascientific.com/

Submit Article: www.actascientific.com/submission.php

Email us: editor@actascientific.com

Contact us: +919182824667 